\title{
Longevities of adult Chironomidae (Diptera) From TWO STREAMS IN ICELAND
}

\author{
Corrie Nyquist ${ }^{1,}{ }^{*}$, Gísli Már Gíslason², Bruce Vondracek ${ }^{3}$, Leonard C. Ferrington Jr. ${ }^{1}$ \\ ${ }^{1}$ Department of Entomology, 219 Hodson Hall, 1980 Folwell Avenue, University of Minnesota, \\ Saint Paul, Minnesota, USA 55108-6125.E-mail:nyqui095@umn.edu,ferri016@umn.edu \\ ${ }^{2}$ Faculty of Life and Environmental Sciences, School of Engineering and Natural Sciences, Askja, \\ University of Iceland, Reykjavik, Iceland. E-mail: gmg@hi.is \\ ${ }^{3}$ Department of Fisheries, Wildlife and Conservation Biology, 135 Skok Hall, 2003 Upper Buford Circle, \\ University of Minnesota, Saint Paul, Minnesota, USA 55108. E-mail: bvondrac@umn.edu \\ *Corresponding author
}

\begin{abstract}
Mean annual air temperatures are predicted to increase by several degrees in the Arctic. This increase in temperature will likely impact organisms adapted to current conditions. Studies of longevities of winter-active Chironomidae from cold, groundwater-fed streams in Minnesota demonstrate that winter-emerging species are long-lived as adults when incubated at cold or sub-freezing air temperatures post emergence. It is unknown if this holds for species emerging in sub-arctic latitudes during warm months, or if warm air temperatures affect the adults of species emerging from cold and geothermally heated streams. The goal of this study was to determine the effects of exposure to air temperatures predicted by climate change models on the longevities of Chironomidae emerging from both cold and geothermally heated larval environments. Chironomidae were trapped at emergence from two groundwater-fed streams with contrasting (warm and cold) thermal regimes at the Hengladalir valleys in the Hengill alpine geothermal area in southwestern Iceland over 4 days in July 2018. Adults $(\mathrm{N}=102)$ were randomly divided into two treatments and incubated at either $20^{\circ} \mathrm{C}$ or $6^{\circ} \mathrm{C}$ for $28-32$ days to determine influence of source stream and incubation temperature on adult longevity. These temperatures were selected to simulate current and predicted water and air temperatures that adult chironomids are likely to be exposed to with climate change. Adults incubated at $6^{\circ} \mathrm{C}$ survived longer than adults incubated at $20^{\circ} \mathrm{C}$ irrespective of source stream. All adults incubated at $20^{\circ} \mathrm{C}$ died within $1-5$ days post-emergence. Longevities of taxa incubated at $6^{\circ} \mathrm{C}$ ranged from 13 to more than 32 days. Species of Diame$s a$ exhibited the greatest longevities, with $41.7 \%$ surviving more than 28-32 days post-emergence at $6^{\circ} \mathrm{C}$. We were unable to determine maximum longevity for Diamesa within the $6^{\circ} \mathrm{C}$ treatment because surviving adults had to be sacrificed at the
\end{abstract}

termination of the experiment on day 32. However, the minimum longevity we report is similar to longevities determined for other Diamesa species and indicates that Diamesa species in Iceland are also long-lived under cold air temperatures. We suggest there may be a difference in longevity between sex, with females living longer than males at cold temperatures. By contrast, we found that both sexes of Diamesa and all other chironomid taxa that we tested are susceptible to warm air temperatures regardless of stream of origin. Therefore, warming climatic temperatures could potentially lead to shortened adult lifespans for these sub-arctic taxa.

\section{Introduction}

Although most species of Chironomidae are known to have a short adult lifespan (Ferrington and Berg 2019), three species of the subfamily Diamesinae, Diamesa mendotae Muttkowski, 1915, Diamesa kohshimai Sæther et Willassen, 1987 and Diamesa yalavia Sæther et Willassen, 1987, have survived for at least 30 days when adults are incubated at cool temperatures (Ferrington et al. 2010, Kohshima 1984). All three long-lived species actively grow and develop as larvae in cold water, then pupate and emerge as adults into climates characterized by air temperatures that often dip below freezing or are at subfreezing temperatures for extended periods (Bouchard and Ferrington 2009, Kohshima 1984). What is not known is whether these three species represent isolated instances of extreme adaptations to cold, or if other cold-adapted species of chironomids that emerge in winter or occur in cold climates have extended longevities as adults. Also unknown is whether extended adult longevity is restricted to the genus Diamesa, or if this characteristic is common for Diamesinae or species of other subfamilies that develop in cold water in concert with Diamesinae (Soszyńska-Maj et al. 2015). 
A significant number of studies discussing the life history of winter-active chironomids have been conducted in Minnesota. The Driftless region of southeastern Minnesota has a high concentration of groundwater-fed streams where the groundwater approximates mean annual air temperature (8$9.5^{\circ} \mathrm{C}$ ) (Anderson and Ferrington 2013, Bouchard and Ferrington 2009, Krider et al. 2013). Winteremerging populations of chironomids are commonly found in the unfrozen stream reaches fed by groundwater. Winter emergence in these streams consists mostly of species of Orthocladiinae and Diamesinae (Nyquist et al. 2020), and historical records indicate that Diamesa are active on snow in Minnesota (Hansen and Cook 1976). Adults emerge in water temperatures between $0^{\circ}$ to $10^{\circ} \mathrm{C}$ and can be found walking and mating on snow at air temperatures well below $0^{\circ} \mathrm{C}$, including days when air temperatures do not exceed $-8^{\circ} \mathrm{C}$ (Ferrington et al. 2010). In laboratory studies, adults of D. mendotae live between 10-30 days when held at $6^{\circ} \mathrm{C}$ after collection from snowbanks near streams (Ferrington et al. 2010). This species also survives over 60 days when incubated at sub-freezing temperatures (Anderson et al. 2013, Mazack et al. 2015). The extended longevity of adult Diamesa has been hypothesized as an adaptation to increase the probability of finding a mate and successfully reproducing under the harsh conditions of winter in Minnesota (Ferrington 2019).

The Hengladalir valleys of the Hengill alpine geothermal area in southwestern Iceland has been a focus of ecological research on dynamics of groundwater-fed streams of differing temperatures (Friberg et al. 2009, Gudmundsdottir et al. 2011, Hannesdottir et al. 2013, O'Gorman 2016, Woodward et al. 2010). Numerous springs in this valley have contrasting thermal regimes ranging from 22.0 to $6.6^{\circ} \mathrm{C}$ during the summer. These contrasting thermal regimes emanate from cold groundwater sources and snowmelt, or groundwater that is warmed by contacting volcanically heated bedrock and soils (Friberg et al. 2009, Hannesdottir et al. 2013). The springs are within 1 meter to several hundred meters of each other (Gudmundsdottir et al. 2011, O'Gorman 2016, Woodward et al. 2010) and have similar riparian vegetation along their spring runs. The chironomid fauna of the streams are well documented and include Diamesa and other cold-water genera including Eukiefferiella and Orthocladius (Hannesdottir et al. 2013). The streams also have populations of more eurythermal species, such as Micropsectra atrofasciata (Kieffer, 1911), that are common in the groundwater-fed streams that have geothermally heated groundwater sources (Hannesdottir et al. 2013). The varying thermal regimes and species compositions provides opportunity to test the longevities of chironomid species among predominant subfamilies whose larvae grow in contrasting thermal regimes but emerge as adults into similar air temperature conditions. This system is of interest in the context of climate change since warming thermal regimes are expected as mean annual air temperatures continue to increase in the arctic (Woodward et al. 2010). Warming thermal regimes of water may affect development times of larvae, and increased air temperatures may alter adult longevity after emergence. Therefore, studying the longevity of taxa emerging from contrasting thermal regimes and comparing results to what has been previously discovered for cold-adapted genera in other geographic areas can provide critical insight into how climate warming will impact cold-adapted taxa at large spatial scales.

Goals for this research were to (1) determine longevities of adults emerging from two Icelandic groundwater-fed streams with contrasting water temperature conditions, when incubated at two contrasting air temperatures, and (2) determine if longevities of Diamesa species emerging in summer at Hengill are similar to longevities documented under controlled conditions for $D$. mendotae emerging during winter from streams in Minnesota (Ferrington et al. 2011).

\section{Methods and materials}

Site description: Two groundwater-fed streams were selected for study in the Hengladalir valleys of the Hengill alpine geothermal area located approximately $30 \mathrm{~km}$ east of Reykjavík $\left(64^{\circ} 03^{\prime} \mathrm{N}\right.$ : $\left.021^{\circ} 18^{\prime} \mathrm{W}\right)$. These streams are in close proximity to one another (at some places $\sim 2 \mathrm{~m}$ apart) but have contrasting thermal regimes (Fig. 1). The cold stream, IS7, is fed by a cold groundwater source and maintains a mean summer temperature of $6.6 \pm 1.3^{\circ} \mathrm{C}\left(5.4 \pm 1.4^{\circ} \mathrm{C}\right.$ mean annual temperature), whereas the warm stream, IS8, is geothermally heated, with a mean summer temperature of $22.0 \pm 0.8^{\circ} \mathrm{C}\left(21.3 \pm 1.0^{\circ} \mathrm{C}\right.$ mean annual temperature) (Hannesdottir et al. 2013). The streams flow over similar terrain and both streams flow into the larger River Hengladalsá (Fig. 1).

Field collection and lab study: Uninjured and recently emerged adult chironomids were collected using 8 close-weave muslin emergence traps, 3 on IS7 and 5 on IS8; additional traps were placed on IS8 since previous research on IS8 indicated that this stream has lower numbers of emerging adults compared to IS7 (Gisli Mar Gislason personal 
observation, July 2018). Collections were made daily from 5-8 July 2018 at approximately the same time each day (1000-1300). Adult chironomids were collected individually into one-dram snap top vials using an aspirator and transported to the laboratory in a cooler. A small amount of stream water (approximately 10-20\% the volume of the vial) was added to each vial during collection to prevent desiccation. Adults were sorted by sex to have equal numbers of each sex within each treatment, and then were randomly assigned to one of two treatment groups for incubation at either constant $6^{\circ} \mathrm{C}$ or constant $20^{\circ} \mathrm{C}$. Adults were kept in total darkness except when assessed for survival, as stipulated in the protocol used by Ferrington (2019) in previous studies of longevity (Ferrington, unpublished lab protocol). No food was provided because adult chironomids are nonfeeding. The two temperatures were selected to approximate conditions of the larval habitats, and air temperatures that adults could be exposed to after emergence. Air temperatures during the summer in southern Iceland range from approximately $6^{\circ} \mathrm{C}$ (World Weather Information Service 2020) to more than $10^{\circ} \mathrm{C}$ (Degenhardt and Ólafsson 2019). Thus, our $6^{\circ} \mathrm{C}$ treatment simulated coolest summer air temperatures. Based on the most extreme climate warming models, a $10^{\circ} \mathrm{C}$ increase in mean air temperature is a possibility for the arctic (Bintanja and Andry 2017). Therefore, the $20^{\circ} \mathrm{C}$ treatment simulates temperatures that adults could be exposed to in the most severe climate scenario. We chose the lower temperature treatment to provide continuity with protocols of adult longevity experiments conducted during winter in Minnesota

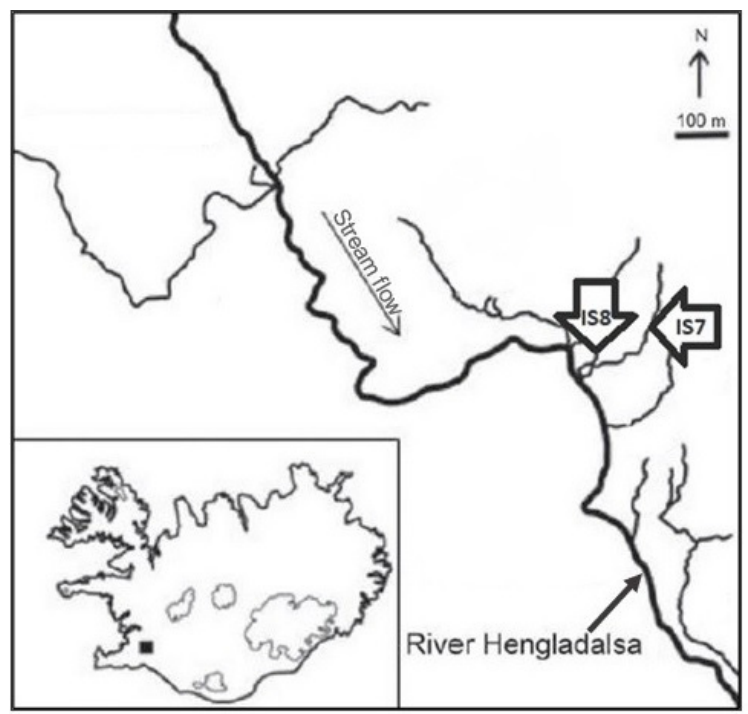

Figure 1. Map of research streams IS7 and IS8 within the Hengladalir valleys of the Hengill alpine geothermal area, Iceland (inset) (adapted from Hannesdottir et al. 2013). at $6^{\circ} \mathrm{C}$ (Ferrington, unpublished standard operating procedure).

Individual adults were randomly assigned to incubation treatments using physical attributes but could not be unambiguously differentiated to genus until after they died and were preserved. Consequently, specimens were not always evenly assigned by genus to treatment groups. Adults were assessed daily for survival using the protocol outlined in Ferrington (2019). Minimal handling was employed to prevent any influence on longevity. Individuals not exhibiting physical movement when the vials were tapped were judged as dead and preserved in $90 \% \mathrm{EtOH}$. The experiment was terminated at 32 days. All individuals still alive on day 32 were sacrificed by preserving them in $90 \%$ ETOH. Depending on the date of collection, the surviving adults preserved on day 32 of the experiment were 28-32 days post-emergence.

Adults were identified to genus following preservation using Weiderholm (1989). Longevities of Diamesa were analyzed at the genus-level because females could not be unambiguously differentiated to species. Data for both male and female Diamesa were summed to estimate longevity. Males of Orthocladiinae and Tanytarsini were also identified and analyzed at genus-level. However, not all Orthocladiinae and Tanytarsini females could be reliably identified to genus, and therefore the females are treated at subfamily and tribe levels, respectively, and analyzed independent of the totals for males.

Temperature effects on longevity of Diamesa adults were analyzed using a generalized linear mixed-effects model (GLME) with a Poisson distribution from the lme4 package (Bates et al. 2015) in RStudio Desktop Version 1.1.423 (R Core Team 2017). Only data for Diamesa from IS7 were analyzed since there was only one Diamesa individual collected from IS8. Residuals for the GLME were more evenly distributed after removing outliers (3 individuals that were dead when checked at day 1 post-collection). Visualization of treatment effects was performed using ggplot2 (Wickham 2016).

Mean longevity was calculated based on time from retrieval in the emergence traps to death in the laboratory for all individuals that died during incubation (as in Ferrington et al. 2010, Anderson et al. 2013, and Mazack et al. 2014). Survival estimates for Diamesa were also calculated using the Kaplan-Meier nonparameteric estimation approach (Hintz, NCSS Version 2007.lnk). This approach was only employed for Diamesa because over half of the adult Diamesa collected survived for the du- 
ration of the study. For this analysis, adults dying during the first 24 hours were coded as left censored, those dying after 24 hours but before day 32 were coded as interval censored, and adults surviving to day 32 were coded as right censored (Klein and Moeschberger 1997).

\section{Results}

Of the total of 135 adults collected, 10 individuals were removed from the analyses: 3 adults could not be reliably identified, 3 adults died in transit or upon arrival to the laboratory, 1 adult was removed because there was an error in recording the behavior during observation, and 3 adults were outliers for the longevity analysis. Twenty-three adults $(18 \%)$ incubated at $6^{\circ} \mathrm{C}$ survived the duration of incubation (21 of these were Diamesa) and had to be sacrificed on termination of the experiment on day 32. Therefore, longevities of 102 adults were determined for identifiable specimens that died during the experiment. Tables 1 and 2 indicate the mean longevities of each taxon collected based on treatment. However, for the taxa which had individuals that survived and needed to be sacrificed upon termination of the experiment, an asterisk shows the mean longevity computed here, which should be considered as a minimum estimate (Table 1).

Emergence from IS7 (95 adults, 7 taxa) exceeded emergence from IS8 ( 7 adults, 5 taxa) resulting in uneven numbers of adults available for incubation. All specimens incubated at $20^{\circ} \mathrm{C}$ had reduced longevities regardless of taxon and stream origin (Tables 1 and 2). Sixty-two Diamesa were collected from IS7 (Table 1) and 1 from IS8 (Ta-

Table 1. Mean longevities of taxa collected from stream IS7 that died during the two temperature treatments. (* See text for corresponding Kaplan-Meier nonparametric estimates of longevity). The longevity for Diamesa is a minimum longevity estimate since 21 adults survived the incubation and had to be sacrificed.

\begin{tabular}{llllll}
\hline Taxon & Stream & $\begin{array}{l}\text { Incubation } \\
\text { Treatment }\end{array}$ & $\begin{array}{l}\text { Total } \\
\text { Incubated }\end{array}$ & Number Died & $\begin{array}{l}\text { Longevity of } \\
\text { Individuals } \\
\text { That Died }\end{array}$ \\
\hline Diamesa & IS7 (Cold) & $6^{\circ} \mathrm{C}$ & 33 & 12 & $19.9^{*}$ \\
Eukiefferialla & IS7 (Cold) & $6^{\circ} \mathrm{C}$ & 2 & 1 & 18.0 \\
Micropsectra & IS7 (Cold) & $6^{\circ} \mathrm{C}$ & 5 & 5 & 19.8 \\
Orthocladiinae & IS7 (Cold) & $6^{\circ} \mathrm{C}$ & 6 & 5 & 18.2 \\
Orthocladius & IS7 (Cold) & $6^{\circ} \mathrm{C}$ & 3 & 3 & 13.0 \\
Thienemanniella & IS7 (Cold) & $6^{\circ} \mathrm{C}$ & 8 & 8 & 20.8 \\
Diamesa & IS7 (Cold) & $20^{\circ} \mathrm{C}$ & 29 & 29 & $3.8 *$ \\
Eukiefferiella & IS7 (Cold) & $20^{\circ} \mathrm{C}$ & 3 & 3 & 5.0 \\
Micropsectra & IS7 (Cold) & $20^{\circ} \mathrm{C}$ & 3 & 3 & 3.7 \\
Orthocladiinae & IS7 (Cold) & $20^{\circ} \mathrm{C}$ & 19 & 19 & 3.0 \\
Tanytarsini & IS7 (Cold) & $20^{\circ} \mathrm{C}$ & 1 & 1 & 4.0 \\
Thienemanniella & IS7 (Cold) & $20^{\circ} \mathrm{C}$ & 6 & 6 & 3.2 \\
Total & & & $\mathbf{1 1 8}$ & $\mathbf{9 5}$ & \\
\hline
\end{tabular}

Table 2. Mean longevities of taxa collected from stream IS8 that died during the two temperature treatments.

\begin{tabular}{llllll}
\hline Taxon & Stream & $\begin{array}{l}\text { Incubation } \\
\text { Treatment }\end{array}$ & $\begin{array}{l}\text { Total } \\
\text { Incubated }\end{array}$ & Number Died & $\begin{array}{l}\text { Longevity of } \\
\text { Individuals } \\
\text { That Died }\end{array}$ \\
\hline Eukiefferiella & IS8 (Warm) & $6^{\circ} \mathrm{C}$ & 2 & 2 & 22.5 \\
Tanytarsini & IS8 (Warm) & $6^{\circ} \mathrm{C}$ & 2 & 2 & 11.5 \\
Diamesa & IS8 (Warm) & $20^{\circ} \mathrm{C}$ & 1 & 1 & 2.0 \\
Micropsectra & IS8 (Warm) & $20^{\circ} \mathrm{C}$ & 1 & 1 & 1.0 \\
Orthocladiinae & IS8 (Warm) & $20^{\circ} \mathrm{C}$ & 1 & 1 & 5.0 \\
Total & & & 7 & 7 & \\
\hline
\end{tabular}




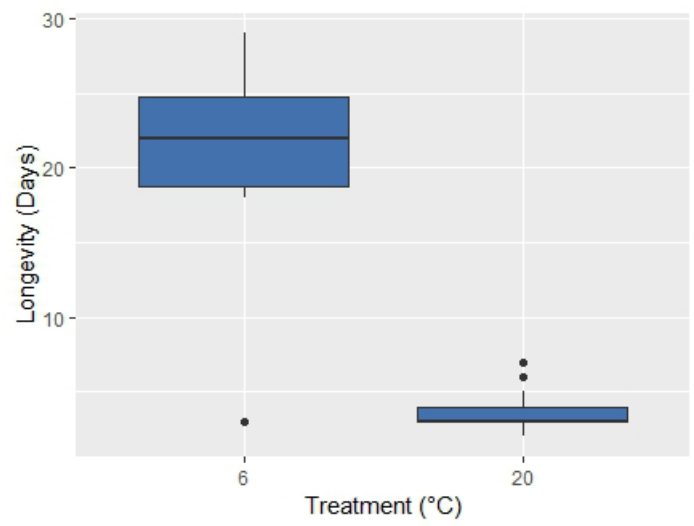

Figure 2. Comparison of Diamesa longevity from stream IS7 between treatments, based only on individuals (males and females together) that died during the incubation period. Results are shown for 12 individuals in the $6^{\circ} \mathrm{C}$ treatment and 29 in the $20^{\circ} \mathrm{C}$ treatment. The black bars indicate median longevity of adults that died.

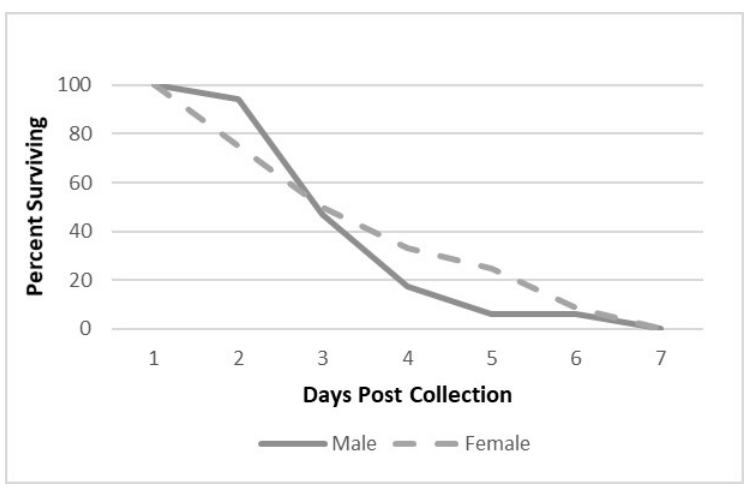

Figure 3. Percent of surviving adult females $(n=12)$ and males $(\mathrm{n}=17)$ of Diamesa versus days post collection incubated at $20^{\circ} \mathrm{C}$.

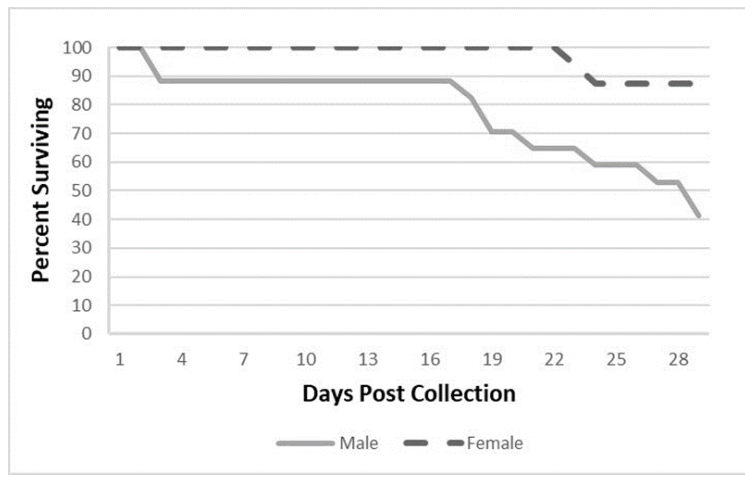

Figure 4. Percent of surviving adult females $(n=16)$ and males $(\mathrm{n}=17)$ of Diamesa versus days post collection incubated at $6^{\circ} \mathrm{C}$. Results are shown for all Diamesa, including individuals that did not die during the experiment but were sacrificed at the end of the experiment on day 32 . ble 2). Twenty-five Orthocladiinae were identified from IS7 (Table 1). Only one individual identified to Orthocladiinae was collected from IS8 (Table 2). Fourteen individuals of Thienemanniella were collected from IS7 (Table 1). However, none were collected from IS8 (Table 2). Within the $6^{\circ} \mathrm{C}$ treatment, only 12 Diamesa died naturally by day 28 ; 21 survived and were preserved on day 32 of the study (Table 1). In addition, one individual of the subfamily Orthocladiinae and one Eukiefferiella incubated in the $6^{\circ} \mathrm{C}$ treatment survived to the end of the experiment and both were preserved on day 32 (Table 1).

The mean longevity of Diamesa in the $20^{\circ} \mathrm{C}$ treatment was 3.8 days, whereas the mean longevity of individuals held at $6^{\circ} \mathrm{C}$ was 19.9 days, equating to an $81 \%$ reduction in longevity at the higher incubation temperature. Longevities were significantly different between treatments $(\mathrm{P}<0.0001, \mathrm{Z}$ value $=$ -13.14) (Fig. 2); however, this test was based on 12 individuals that died naturally within the $6^{\circ} \mathrm{C}$ treatment and, therefore, indicates a minimum longevity estimate. Forty-seven percent of females and $50 \%$ of males survived to day 3 in the warm treatment, but all died by day 7 (Fig. 3). The KaplanMeier nonparametric estimates of $50 \%$ survival (regardless of sex) in the warm treatment was 3.6 days $(95 \% \mathrm{CI}=3.3-4.3$ days), and 3.0 days $(95 \%$ $\mathrm{CI}=2-4$ ) for $75 \%$ survival. For the cold treatment, $88 \%$ of females survived to day 28 ; whereas $53 \%$ of males survived to day 28 (Fig. 4). In contrast to results for incubation at $20^{\circ} \mathrm{C}$, the corresponding Kaplan-Meier nonparametric estimate of longevity for $75 \%$ percent survival of Diamesa adults in the cold treatment was 24 days $(95 \% \mathrm{CI}=18-29)$.

\section{Discussion}

Longevities and cold adaptation: This is the first study of adult longevity for summer-emerging chironomids in relation to thermal regime of parent streams at the Hengill alpine geothermal area. Previous studies of chironomids have demonstrated the influence of thermal regime on emergence, taxonomic composition and abundances (e.g., Hannesdottir et al. 2013), but influences on other aspects of the life history, especially responses to temperature by adults, need to be better understood for comparative life-history analyses and refining hypotheses relating more generally to global warming. Our study is especially noteworthy because summer emergence from the cold, groundwater-fed streams at Hengill consisted of several chironomid genera, including Diamesa and Orthocladius, that characterize emergence during winter in several mid-latitudes of the northern hemisphere 
(Nyquist et al. 2020), where species of Diamesa have been shown to be long lived after emergence when incubated at cool temperatures (Anderson et al. 2013, Ferrington et al. 2010, Mazack et al. 2014). Although we were not able to determine the maximum longevity for Diamesa because of time constraints associated with our experimental design, we are able to demonstrate that summer emerging species of Diamesa and Orthocladius are long-lived, potentially indicating that longer adult life spans are common among Diamesinae, and even cold-adapted Orthocladiinae, including species of Orthocladius and Eukiefferiella. For instance, even though fewer in number, adults of Thienemanniella had longevities comparable to the Diamesa that died naturally, although only by less than a day. The other Orthocladiini collected also had longevities comparable to the Diamesa that died naturally at $6^{\circ} \mathrm{C}$.

Although fewer adults were collected from the warm spring run, the general trend of greater longevity when incubated at $6^{\circ} \mathrm{C}$ appears to hold regardless of the stream origin for the taxon. We conclude that adults emerging from both cold and geothermally heated springs are relatively cold adapted during the summer and able to survive longer periods of cold air temperatures regardless of the thermal regime that the immature stages experience. For example, Micropsectra, a genus more commonly found in the warm streams (Hannesdottir et al. 2013) at Hengill, exhibited longevities similar to Diamesa within the cold treatment.

Long duration of the adult stage of cold-adapted midges was first documented by Kohshima (1984) for a "new species of midge" collected on snow and ice of Yala Glacier in Nepal, where adults were active at air temperatures down to $-16^{\circ} \mathrm{C}$. Although only measured once, brachypterous adults collected at 5000-5600 meters elevation and incubated in plastic cups under field conditions displayed sex-related differences in longevities, with $96 \%$ of females surviving for the 35-day duration of the experiment. All males, however, died during the test interval. In the original paper by Kohshima (1984), the adults were presumed to represent a single species. Specimens sent by Kohshima to Sæther and Willassen (1987) for identification were determined to be Diamesa, but the collections contained two undescribed species, subsequently described as Diamesa kohshimai Sæther et Willassen and Diamesa yalavia Sæther et Willassen. The ratios of the two species in the experiment by Kohshima (1984) were not determined, but females of both species can be assumed to be among those that survived the 35-day duration of the experiment.
We collected too few females in this study to determine statistically significant differences in longevity between the sexes. However, graphically (Figure 4), our results from the $6^{\circ} \mathrm{C}$ treatment suggest that females may live longer than males under cold temperatures. This interpretation is consistent with the conclusions of long adult portion of the life cycle by Kohshima (1984). However, future work is needed to confirm whether this difference is significant and holds for Diamesa and other cold-adapted taxa at Hengill.

Winter-emerging species of Chironomidae in unfrozen, temperate streams in the United States show adaptations to cold similar to those observed by Kohshima (1984). Ferrington (2000) found that species of Orthocladiinae and Diamesinae dominate winter emergence, as was generalized by Armitage (1995) for temperate zones of the northern hemisphere, and that species of both subfamilies emerge and are active as adults at sub-freezing temperatures. Adults of $D$. mendotae have been observed to supercool to $-19.7 \pm 0.58^{\circ} \mathrm{C}$ with some individuals able to supercool to $-25.8^{\circ} \mathrm{C}$ (Bouchard et al. 2006). Species of Diamesa were among the most cold-adapted of 51 species of chironomids that emerged as adults during the coldest months of the year in Kansas (Ferrington 2000). Thus, it is not surprising that we found the Diamesa within our study to be long-lived under cold temperatures. However, other taxa collected from IS7, such as Eukiefferiella and Orthocladius, are also part of the winter-emerging, cold-adapted fauna of Kansas and Minnesota (Nyquist et al. 2020), and Anderson et al. (2011) documented that winter emergence of Diamesa and several species of Orthocladiinae were restricted to small intermittent or groundwater-dominated stream reaches in Kansas. Thus, the long lifespans of Orthocladiinae under cold temperatures in our study is consistent with the evidence for cold adaptation in subarctic Orthocladiinae found by other studies.

Climate change implications: The mean air temperature during emergence (July 5-8, 2018) was $4.3^{\circ} \mathrm{C}$ and the mean air temperate for the summer of 2018 (June 1-August 31) was $5.7^{\circ} \mathrm{C}$ (temperature data from Skardsmyrarfjall Weather Station, Iceland). However, the summer of 2018 was atypically cool. Air temperatures typically average around $10.7^{\circ} \mathrm{C}$ from June through August for the south coast of Iceland (Degenhardt and Ólafsson 2019). Therefore, our cold treatment reflects cool summer temperatures that adults may be exposed to, and indicate that adult chironomids are likely to be naturally long lived at $6^{\circ} \mathrm{C}$ during the summer since even summer temperatures do not typically 
reach $20^{\circ} \mathrm{C}$. However, predicted changes in Arctic mean annual air temperature due to climate change range from 4.2 to $8.3^{\circ} \mathrm{C}$ based on different climatic scenarios (Stocker et al., 2013) with some models predicting up to a $10.6^{\circ} \mathrm{C}$ increase in temperature based on intermodel standard deviation (Bintanja and Andry 2017). Thus, air temperatures in the arctic could approach $20^{\circ} \mathrm{C}$ as climate change proceeds, and the longevities of adults incubated at $20^{\circ} \mathrm{C}$ provide insight into how climate change could potentially alter the lifespans of chironomids in Iceland and other Arctic regions. Although oviposition rates and fecundity were not assessed in this study, they may also be altered by warming temperatures and, thus, warrant further investigation.

Although capable of living an extended period as adults in cool conditions, exposure to warm air temperatures appears to affect the behavior and longevity of cold-adapted species. For instance, Kohshima (1984) commented that adults collected from the Yala Glacier in Nepal were "very sensitive to a temperature as high as that of the human hand" and "became hyperactive for a few seconds, but were paralysed within about $20 \mathrm{~s}$ " when held in a human palm. Presumably, the rapid heating could affect adult longevity. We found reduced longevities of Diamesa when incubated at $20^{\circ} \mathrm{C}$ and the warm treatment had a negative effect on longevities of all taxa. This effect on adults suggests that cold-adapted chironomids could be extremely vulnerable to increasing air temperatures associated with global warming, especially if reduction of the adult phase of the life cycle reduces their probability of securing a mate and reproducing successfully.

Future research directions: Previous determinations of longevities for adults of $D$. mendotae were based on adults collected from snow adjacent to trout streams, and it was originally presumed that they represented recently emerged individuals (Anderson et al. 2013, Ferrington et al. 2010). However, subsequent findings indicate that specimens incubated in snow, or at controlled sub-freezing temperatures, can survive in vials for extended periods. Thus, we suggest some individuals collected from snow in these earlier studies could have emerged several or many days before being collected, especially if they congregate in protected areas such as under snow that is drifted and overhangs some of the unfrozen stream bed. If this is the case, estimates in previous literature must be re-interpreted as minimum longevity estimates, and actual longevities could be substantially longer. Future research should be conducted to quantify differences in longevity between trapped individuals and individuals collected off snow.

Adults used in this study were trapped at emergence, and the traps were emptied daily, thus the ages of adults (post-emergence) did not exceed one day at the beginning of the incubation periods. Consequently, the long durations of survival of adults reported for this study accurately represent length of time survived up to and including 32 days, and therefore, the difference between survival estimates of Diamesa collected at Hengill relative to studies of $D$. mendotae in Minnesota may largely reflect difference in collection methods rather than difference that corresponds to the different species involved. Therefore, we suggest the use of emergence traps in future studies of $D$. mendotae to provide more comparable estimates of species-level difference in adult longevity.

Winter-active Diamesa have been observed emerging under subzero temperatures on the River Laxá in Northern Iceland (Gislason personal observation, 2019). However, the life histories of cold adapted winter-emerging species have not been extensively documented for these populations. In addition, no previous studies have quantitatively measured adult longevity of specimens collected from snow or documented how prevalent winter emergence is in Iceland. Thus, winter-active chironomids in Iceland may also possess long lifespans as adults similar to $D$. mendotae. Emergence of Diamesa in winter on the River Laxá provides an opportunity for future research related to climate change models and other aspects of adaptation to cold in life cycles of chironomids. For example, here we demonstrate that summer emerging Dia$m e s a$, whose larvae inhabit cold, groundwater-fed streams at Hengill, are long lived and can survive beyond 29-32 days when incubated at $6^{\circ} \mathrm{C}$ in the laboratory. These results are comparable to the longevities of $D$. kohshimai and D. yalavia from Nepal (Kohshima 1984) and D. mendotae in Minnesota (Ferrington et al. 2010) which has winter activity facilitated by freeze resistance (Bouchard et al. 2006). Therefore, we expect that the winteremerging species in Iceland may also survive for extended periods at sub-freezing air temperatures if they also can depress freezing points similar to D. mendotae (Carrillo et al. 2004).

Conclusion: Chironomid adults in this study emerged from both cold and geothermally heated springs and are cold adapted during the summer. Air temperatures in the arctic could approach $20^{\circ} \mathrm{C}$ as climate change proceeds, and the longevities of adults incubated at $20^{\circ} \mathrm{C}$ provide insight into how 
climate change could potentially alter the lifespans of chironomids in Iceland and other Arctic regions. Future research efforts should be directed toward investigating effects of climate warming on winter-active chironomids in Iceland, since there is evidence for reduced lifespans under warm temperatures for both summer emerging Icelandic species and shared taxonomic groups which are winter-emerging in the subarctic.

\section{Acknowledgements}

This project was funded through awards to Corrie Nyquist (1) from the Bell Museum Natural History Award through the Frank McKinney Fellowship and (2) the Moos Graduate Research Fellowship in Aquatic Biology. Special thanks to our co-author, Gisli Mar Gislason at the University of Iceland, for hosting the research providing input on the field and laboratory methods and use of laboratory space. Additional support for this project was provided by a Minnesota Agricultural Experiment Station Grant (17-031) to Leonard C. Ferrington Jr. as Principal Investigator, and the Department of Entomology at the University of Minnesota. This paper is published under the auspices of the Chironomidae Research Group, also at the Department of Entomology, University of Minnesota.

\section{References}

Anderson, A.M., Bouchard, R.W. Jr. and Ferrington, L.C.Jr. 2011. Hibernal emergence of Chironomidae (Diptera) in relation to stream size in Kansas, USA. - Proceedings of the 17th International Symposium on Chironomidae, Nankai University, Tianjing, China.

Anderson, A.M. and Ferrington, L.C.Jr. 2013. Resistance and resilience of winter-emerging Chironomidae (Diptera) to a flood event: implications for Minnesota trout streams. - Hydrobiologia 707: 59-71. DOI: https://doi. org/10.1007/s10750-012-1406-4

Anderson, A.M., Kranzfelder, P., Bouchard, R.W. and Ferrington, L.C.Jr. 2013. Survivorship and Longevity of Diamesa mendotae Muttkowski (Diptera: Chironomidae) Under Snow. - Journal of Entomological and Acarological Research 45:22-26. DOI: https://doi.org/10.4081/ jear.2013.e6

Bates, D., Maechler, M., Bolker, B. and Walker, S. 2015. Fitting linear mixed-effects models using lme4. - Journal of Statistical Software 67: 1-48. DOI: http://dx.doi.org/10.18637/jss. $\underline{\mathrm{v} 067 . \mathrm{i} 01}$

Bintanja, R. and Andry, O. 2017. Towards a rain- dominated Arctic. - Nature Climate Change 7: 263-267. DOI: https://doi.org/10.1038/nclimate 3240

Bouchard, R.W.Jr., Carrillo, M.A., Kells, S.A. and Ferrington, L.C.Jr. 2006. Freeze tolerance in larvae of the winter-active Diamesa mendotae Muttkowski (Diptera: Chironomidae): a contrast to adult strategy for survival at low temperatures. - Hydrobiologia 568:403-416. DOI: https://doi.org/10.1007/s10750-006-0200-6

Bouchard, R.W.Jr. and Ferrington, L.C.Jr. 2008. Determination of Chironomidae thermal preferences and thermal partitioning among closely related taxa in Minnesota streams using surface floating pupal exuviae. - Boletim do Museu Municipal do Funchal (História Natural) No. 13:197-204.

Bouchard, R.W.Jr. and Ferrington, L.C.Jr. 2009. Winter growth, development, and emergence of Diamesa mendotae (Diptera: Chironomidae) in Minnesota streams. - Environmental Entomology 38: 250-259. DOI: https://doi. org/10.1603/022.038.0131

Carrillo, M.A., Cannon, C.A. and Ferrington, L.C.Jr. 2004. Effect of sex and age on the supercooling point of the winter-active Diamesa mendotae Muttkowski (Diptera:Chironomidae). - Aquatic Insects 26:243-251. DOI: https://doi. org/10.1080/0165-0420400000320

Degenhardt, L. and Ólafsson, H. 2019. Persistence of observed air temperatures in Iceland. - International Journal of Climatology 39: 1262- 1275. DOI: https://doi.org/10.1002/ joc. 5875

Ferrington, L.C.Jr. 2000. Hibernal emergence patterns of Chironomidae in lotic habitats of Kansas versus ambient air and water temperatures. In Hoffrichter, O. (Ed.) Late Twentieth Century Research on Chironomidae: An Anthology from the 13th International Symposium on Chironomidae. Shaker Verlag, pp. 375-382.

Ferrington, L.C.Jr. 2019. A protocol for recording behavioral activity during longevity studies of adult Chironomidae. - Chironomus Journal of Chironomidae Research 32: 33-41. DOI: https://doi.org/10.5324/cjcr.v0i32.3262

Ferrington, L.C.Jr. and Berg, M.B. 2019. Chapter 27: Chironomidae. In Merritt, R.W., Cummins, K.W. and Berg, M. B. (Ed.) An Introduction to the Aquatic Insects of North America, 5th ed. Kendall Hunt Publishing Company, pp. 11191274. 
Ferrington, L.C., Bouchard, R.W. and Karns, B. 2010. Longevities of Diamesa mendotae Muttkowski, a hibernal emerging species of Chironomidae (Diptera). In Ferrington L.C., (Ed.) Proceedings of the XV International Symposium on Chironomidae. Chironomidae Research Group, University of Minnesota, pp. 22-29.

Hannesdóttir, E.R., Gíslason, G.M., Ólafsson, J.S., Ólafsson, Ó.P. and O’Gorman, E.J. 2013. Increased stream productivity with warming supports higher trophic levels. - Advances in Ecological Research 48: 285-342. DOI: https:// doi.org/10.1016/B978-0-12-417199-2.00005-7

Hansen, D.C. and Cook, E.F. 1976. The systematics and morphology of the Nearctic species of Diamesa Meigen, 1835 (Diptera: Chironomidae). -Memoirs American Entomological Society 30: 1-203.

Hintze, J. 2007. NCSS 2007. NCSS, LLC. Kaysville, Utah, USA. www.ncss.com.

Kohshima, S. 1984. A novel cold-tolerant insect found in a Himalayan glacier. - Nature 310: 225227. DOI: https://doi.org/10.1038/310225a0

Mazack, J.E., Kranzfelder, P., Anderson, A.M., Bouchard, W.R.Jr., Perry, J., Vondracek, B. and Ferrington, L.C.Jr. 2014. Survivorship and longevity of adult Diamesa mendotae Muttkowski, 1915 (Diptera: Chironomidae) at controlled, sub-freezing temperatures. - Aquatic Insects 36: 35-42. DOI: https://doi.org/10.108 $\underline{0 / 01650424.2014 .990040}$

Nyquist, C., Vondracek, B. and Ferrington, L.C.Jr. 2020. The influence of an in-stream thermal gradient on chironomid emergence during winter. - Hydrobiologia 847: 3153-3167. DOI: https://doi.org/10.1007/s10750-020-04281-3

R Core Team. 2017. R: A language and environment for statistical computing. R Foundation for Statistical Computing, Vienna, Austria. https:/www.R-project.org.
Sæther, O.A. and Willassen, E. 1987. Four new species of Diamesa Meigen, 1835 (Diptera, Chironomidae) from the glaciers of Nepal. Entomologica Scandinavica Supplement 29: 189-203.

Soszyńska-Maj, A., Paasivirta, L. and Gilka, W. 2015. Why on snow? Winter emergence strategies of snow-active Chironomidae (Diptera) in Poland. - Insect Science 23: 754-770. DOI: https://doi.org/10.1111/1744-7917.12223

Stocker, T.F., Qin, D., Plattner, G.K., Tignor, M., Allen, S.K., Boschung, J., Nauels, A., Xia,Y., Bex, V. and Midgley, P.M. 2013. Climate Change 2013: The Physical Science Basis. Contribution of Working Group I to the Fifth Assessment Report of the Intergovernmental Panel on Climate Change. Cambridge University Press, $1535 \mathrm{p}$.

Wickham, H. 2016. ggplot2: Elegant Graphics for Data Analysis. Springer-Verlag New York.

Wiederholm, T. (Ed.). 1989. Chironomidae of the Holarctic Region: Keys and Diagnoses. Part 3 Adult Males. Entomologica Scandinavica Supplement No. 34, 532 pp.

Woodward, G., Dybkjaer, J. B., Ólafsson, J. S., Gíslason, G. M., Hannesdóttir, E. R. and Friberg, N. 2010. Sentinel systems on the razor's edge: effects of warming on Arctic geothermal stream ecosystems. - Global Change Biology 16: 1979-1991. DOI: https://doi. org/10.1111/j.1365-2486.2009.02052.x

World Weather Information Service. 2020. World Meteorological Organization, accessed 12 October 2020. https://worldweather.wmo.int/en/ city.html? cityId=189

Article submitted 13. February 2020, accepted by Torbjørn Ekrem 22. November 2020, published 18. February 2021. 